\title{
THIRTY-SEVENTH ANNUAL LIST OF PAPERS
}

READ BEFORE THE AMERICAN MATHEMATICAL SOCIETY AND SUBSEQUENTLY PUBLISHED, INCLUDING REFERENCES TO THE PLACES OF PUBLICATION

ADAMS, C. R. On the irregular cases of the linear ordinary difference equation. Read Dec. 28, 1926. Transactions of this Society, vol. 30, No. 3, pp. 507-541; July, 1928.

- Factorial series in two variables. Read April 6, 1928. This Bulletin, vol. 34, No. 4, pp. 473-475; July-Aug., 1928.

Alexander, J. W. Topological invariants of knots and links. Read May 7, 1927. Transactions of this Society, vol. 30, No. 2, pp. 275-306; April, 1928.

Altshiller-Court, N. On four mutually orthogonal circles. Read Sept. 8, 1927. Annals of Mathematics, (2), vol. 29, No. 3, pp. 369-372; July, 1928.

ArChibald, R. G. Diophantine equations in division algebras. Read Oct. 29, 1927. Transactions of this Society, vol. 30, No. 4, pp. 819-837; Oct., 1928.

Ayres, W. L. Note on a theorem concerning continuous curves. Read Feb. 26, 1927. Annals of Mathematics, (2), vol. 28, No. 4, pp. 501-502; Sept., 1927.

- On the structure of a plane continuous curve. Read May 7, 1927. Proceedings of the National Academy of Sciences, vol. 13, No. 11, pp. 749-754; Nov., 1927.

- On the separation of points of a continuous curve by arcs and simple closed curves. Read Feb. 26, 1927. Proceedings of the National Academy of Sciences, vol. 14, No. 3, pp. 201-206; March, 1928.

- An elementary property of bounded domains. Read Oct. 29, 1927. This Bulletin, vol. 34, No. 2, pp. 200-204; March-April, 1928.

Concerning the arc-curves and basic sets of a continuous curve. Read May 7, 1927. Trensactions of this Society, vol. 30, No. 3, pp. 567-578; July, 1928.

- Concerning continuous curves of certain types. Read May 1, 1926. Fundamenta Mathematicae, vol. 11, pp. 132-140; 1928.

Ayres, W. L., and Whyburn, G. T. On continuous curves in $n$ dimensions. Read Oct. 29, 1927. This Bulletin, vol. 34, No. 3, pp. 349-360; MayJune, 1928.

Ballantrine, J. P. A generalization of the calculus of finite differences to include the differential calculus. Read Dec. 28, 1923. Annals of Mathematics, (2), vol. 29, No. 1, pp. 14-16; Dec., 1927.

BATCHELDER, P. M. An introduction to linear difference equations. Read, in part, April 26, 1913. Cambridge, Mass., Harvard University Press, 1927. $8+209$ pp.

Bateman, $H$. Transverse seismic waves on the surface of a semi-infinite 
solid composed of heterogeneous material. Read (San Francisco Section) Oct. 29, 1927. This Bulletin, vol. 34, No. 3, pp. 343-348; May-June, 1928.

BELL, E. T. Periodic functions of $n$ variables connected with an algebraic number field of degree $n$. Read Jan. 1, 1926. Quarterly Journal of Mathematics, vol. 50, No. 4, pp. 314-328; Sept., 1927.

- Numerical functions of multipartite integers and compound partitions. Read (San Francisco Section) June 18, 1927. American Journal of Mathematics, vol. 49, No. 4, pp. 489-510; Oct., 1927.

On the arithmetic of abelina (sic) functions. Read (San Francisco Section) Oct. 29, 1927. Proceedings of the National Academy of Sciences, vol. 13, No. 11, pp. 754-758; Nov., 1927.

Partition polynomials. Read (San Francisco Section) June 18, 1927. Annals of Mathematics, (2), vol. 29, No. 1, pp. 38-46; Dec., 1927.

Algebraic arithmetic. Read Sept. 6-10, 1927. American Mathematical Society Colloquium Publications, vol. 7; 1927. 4+180 pp.

- A property of resultants. Read (San Francisco Section) April 7, 1928. Messenger of Mathematics, vol. 57, No. 9, pp. 141-144; Jan., 1928.

Certain completely solvable systems of simultaneous diophantine equations. Read (San Francisco Section) April 7, 1928. American Mathematical Monthly, vol. 35, No. 5, pp. 239-241; May, 1928.

Remark on the number of classes of binary quadratic forms of a given negative determinant. Read (San Francisco Section) April 7, 1928. Proceedings of the National Academy of Sciences, vol. 14, No. 5, pp. 430-431; May, 1928.

Ternary characteristics of primes. Read (San Francisco Section) April 7, 1928. This Bulletin, vol. 34, No. 3, pp. 323-328; May-June, 1928.

A generalization of circulants. Read (San Francisco Section) April 7, 1928. Proceedings of the Edinburgh Mathematical Society, (2), vol. 1, part 3, pp. 177-181; July, 1928.

Certain class-number relations implied in the Nachlass of Gauss. Read (San Francisco Section) April 7, 1928. This Bulletin, vol. 34, No. 4, pp. 490-494; July-Aug., 1928.

- Note on difference equations defining enumerative arithmetical functions. Read (San Francisco Section) April 7, 1928. Bulletin of the Calcutta Mathematical Society, vol. 19, No. 3, pp. 135-138; Sept., 1928.

Bender, H. A. On groups of order $p^{m}, p$ being an odd prime number, which contain an abelian subgroup of order $p^{m-1}$. Read April 10, 1925, and Sept. 9, 1926. Annals of Mathematics, (2), vol. 29, No. 1, pp. 89-94; Dec., 1927.

BIRKHoff, G. D. On the periodic motions of dynamical systems. Read Sept. 9, 1927. Acta Mathematica, vol. 50, Nos. 3-4, pp. 359-379; 1927.

—- Dynamical systems. Read Sept. 8-11, 1920. American Mathematical Society Colloquium Publications, vol. 9; 1927. 8+295 pp.

BogolioubofF, N., and Kryloff, N. On Rayleigh's principle in the theory of the differential equations of mathematical physics and on 
Euler's method in calculus of variations. Read Sept. 9, 1926. Annals of Mathematics, (2), vol. 29, No. 3, pp. 255-275; July, 1928.

Brown, E. W. Resonance in the solar system. Read Dec. 28, 1927. This Bulletin, vol. 34, No. 3, pp. 265-289; May-June, 1928.

A remainder formula and its use in the development of the disturbing function by harmonic analysis. Read (San Francisco Section) April 7, 1928. Monthly Notices of the Royal Astronomical Society, vol. 88, No. 8, pp. 624-634; June, 1928.

BRowne, E. T. The characteristic equation of a matrix. Read Dec. 29, 1927. This Bulletin, vol. 34, No. 3, pp. 363-368; May-June, 1928.

CaIRns, W. D. Development of functions in a system of approximately orthogonal functions. Read (San Francisco Section) April 2, 1927. Annals of Mathematics, (2), vol. 28, No. 4, pp. 503-514; Sept., 1927.

Cajori, F. Briefe von C. H. Schumacher und W. Struve an F. R. Hassler in Amerika. Read (San Francisco Section) April 2, 1927. Zeitschrift für Instrumentenkunde, vol. 47, No. 11, pp. 532-536; Nov., 1927.

- The earliest arithmetic published in America. Read (San Francisco Section) April 2, 1927. Isis, vol. 9, No. 3, pp. 391-401; Dec., 1927. Robert Burton's horoscope and the year of his birth. Read (San Francisco Section) Oct. 29, 1927. Popular Astronomy, vol. 36, No. 1, pp. 9-11; Jan., 1928.

- A comparison of methods of determining calendar dates by finger reckoning. Read (San Francisco Section) Oct. 29, 1927. Archeion, vol. 9, No. 1, pp. 31-42; Jan.-March, 1928.

- Surveying and astronomical instruments used in America before the nineteenth century. Read (San Francisco Section) Oct. 25,1919. Printed in The Early Mathematical Sciences in North and South A merica, Boston, The Gorham Press, 1928. 156 pp.

CAMP, C. C. An expansion involving $p$ inseparable parameters associated with a partial differential equation. Read Sept. 9, 1926. American Journal of Mathematics, vol. 50, No. 2, pp. 259-268; April, 1928.

Campbell, A. D. Pencils of conics in the Galois fields of order $2^{n}$. Read Dec. 29, 1925. American Journal of Mathematics, vol. 49, No. 3, pp. 401-406; July, 1927.

The polar curves of plane algebraic curves in the Galois fields. Read Dec. 28, 1927. This Bulletin, vol. 34, No. 3, pp. 361-363; May-June, 1928.

The discriminant of an $m$-ary quadratic in the Galois fields of order $2^{n}$. Read Dec. 28, 1927. Annals of Mathematics, (2), vol. 29, No. 3, pp. 395-398; July, 1928.

Nets of conics in the Galois fields of order $2^{n}$. Read Dec. 31, 1926. This Bulletin, vol. 34, No. 4, pp. 481-489; July-Aug., 1928.

Coble, A. B., and Morley, F. New results in elimination. Read April 15, 1927. American Journal of Mathematics, vol. 49, No. 4, pp. 463-488; Oct., 1928.

Copeland, A. H. Types of motion of the gyroscope. Read Oct. 29, 1927. Transactions of this Society, vol. 30, No. 4, pp. 737-764; Oct., 1928. 
Cramlet, C. M. A determination of all invariant tensors. Read (San Francisco Section) April 3, 1926. Tôhoku Mathematical Journal, vol. 28, Nos. 3-4, pp. 242-250; Sept., 1927.

The derivation of algebraic invariants by tensor algebra. Read Feb. 26, 1927. This Bulletin, vol. 34, No. 3, pp. 334-342; May-June, 1928.

DAvis, D. R. The inverse problem of the calculus of variations in higher space. Read (San Francisco Section) June 18, 1927. Transactions of this Society, vol. 30, No. 4, pp. 710-736; Oct., 1928.

Davis, H. T. On the factoring of Fredholm minors. Read April 16, 1927. Annals of Mathematics, (2), vol. 29, No. 3, pp. 334-342; July, 1928.

Dickson, L. E. Additive number theory for all quadratic functions. Read Sept. 9, 1927. American Journal of Mathematics, vol. 50, No. 1, pp. 1-48; Jan., 1928.

Simpler proofs of Waring's theorem on cubes, with various generalizations. Read April 15, 1927. Transactions of this Society, vol. 30, No. 1, pp. 1-18; Jan., 1928.

- Generalizations of the theorem of Fermat and Cauchy on polygonal numbers. Read Sept. 9, 1927. This Bulletin, vol. 34, No. 1, pp. 63-72; Jan.-Feb., 1928.

- Extended polygonal numbers. Read Sept. 9, 1927. This Bulletin, vol. 34, No. 2, pp. 205-217; March-April, 1928.

Dines, L. L. A theorem on orthogonal functions with an application to integral inequalities. Read (San Francisco Section) June 12, 1926. Transactions of this Society, vol. 30, No. 2, pp. 425-438; April, 1928.

- A theorem on orthogonal sequences. Read Sept. 8, 1927. Transactions of this Society, vol. 30, No. 2, pp. 439-446; April, 1928.

DorRoH, J. L. Concerning a set of metrical hypotheses for geometry. Read Sept. 9, 1927. Annals of Mathematics, (2), vol. 29, No. 2, pp. 229231; April, 1928.

Douglas, J. Contact transformations of three-space which convert a system of paths into a system of paths. Read May 7, 1927. Proceedings of the National Academy of Sciences, vol. 13, No. 8, pp. 605-607; Aug., 1927.

The analysis situs of the plane when the directed line is taken as element. Read Oct. 28, 1922. American Mathematical Monthly, vol. 35, No. 2, pp. 57-63; Feb., 1928.

- The general geometry of paths. Read May 7, 1927. Annals of Mathematics, (2), vol. 29, No. 2, pp. 143-168; April, 1928.

- A method of numerical solution of the problem of Plateau. Read May 7, 1927. Annals of Mathematics, (2), vol. 29, No. 2, pp. 180-188; April, 1928.

DrACH, J. Détermination des éléments linéaires de Liouville pour lesquels l'équation des lignes géodésiques admet au moins deux intégrales rationnelles en la dérivée première. Read Oct. 30, 1926. Comptes Rendus de l'Académie des Sciences, vol. 185, No. 26, pp. 1568-1570; Dec. 27, 1927. 
Dresden, A. Some philosophical aspects of mathematics. Read Dec. 29, 1927. This Bulletin, vol. 34, No. 4, pp. 438-452; July-Aug., 1928.

EIESLAND, J. Quadratic flat complexes in odd $n$-space and their singular spreads, flat-sphere transformation. Read Sept. 7, 1923, and Sept. 10, 1925. Proceedings of the International Mathematical Congress held in Toronto, vol. I, pp. 863-887; 1928.

EISENHART, L. P. Non-Riemannian geometry. Read Sept. 8-12, 1925. American Mathematical Society Colloquium Publications, vol. 8; 1927. $8+184 \mathrm{pp}$.

ElliotT, W. W. Generalized Green's functions for compatible differential systems. Read Dec. 29, 1926. American Journal of Mathematics, vol. 50, No. 2, pp. 243-258; April, 1928.

EtrLinger, H. J. On the Fredholm integral equation. Read Feb. 26, 1927. Tôhoku Mathematical Journal, vol. 28, Nos. 3-4, pp. 152-163; Sept., 1927.

- Note on Riemann-Stieltjes integrals. Read (Southwestern Section) Nov. 27, 1926. Journal of the London Mathematical Society, vol. 2, No. 4, pp. 245-247; Oct., 1927.

- R. L. Moore's principle and its converse. Read Sept. 9, 1926. Comptes Rendus de Séances de la Société des Sciences et de Lettres de Varsovie, Classe III, vol. 19, pp. 455-460; Dec., 1927.

- Existence theorems for implicit functions of real variables. Read Sept. 9, 1926. This Bulletin, vol.34, No.3, pp.315-318; May-June, 1928.

Evans, G. C. Note on a theorem of Bócher. Read Sept. 9, 1927. American Journal of Mathematics, vol. 50, No. 1, pp. 123-126; Jan., 1928.

- General Neumann problems for the sphere. Read April 16, 1927. American Journal of Mathematics, vol. 50, No. 1, pp. 127-138; Jan., 1928.

FARnum, F. On triadic Cremona nets of plane curves. Read Sept. 9, 1926. American Journal of Mathematics, vol. 50, No. 3, pp. 357-370; July, 1928.

Flanders, D. A. Double elliptic geometry in terms of point, order, and congruence. Read May 7, 1927. Annals of Mathematics, (2), vol. 28, No. 4, pp. 534-548; Sept., 1927.

FORD, W. B. On the behavior of integral functions in distant portions of the plane. Read Sept. 8, 1927. This Bulletin, vol. 34, No. 1, pp. 91106; Jan.-Feb., 1928.

Forsyth, C. H. Amounts of investments at any number of rates of interest. Read Oct. 29, 1927. This Bulletin, vol. 34, No. 6, pp. 770-772; Nov.Dec., 1928.

FrankLIN, P. The classification of quadrics in euclidean $n$-space, by means of covariants. Read Oct. 30, 1926. American Mathematical Monthly, vol. 34, No. 9, pp. 453-467; Nov., 1927.

The canonical form of a one-parameter group. Read Dec. 29, 1926. Annals of Mathematics, (2), vol. 29, No. 2, pp. 113-122; April, 1928. A qualitative definition of the sub- and super-harmonic functions. Read May 7, 1927. Journal of Mathematics and Physics of the Massachusetts Institute of Technology, vol. 7, No. 2, pp. 86-92; June, 1928. 
FrINK, O. On the existence of linear algebras in boolean algebras. Read Jan. 1, 1926. This Bulletin, vol. 34, No. 3, pp. 329-333; May-June, 1928.

GAGE, W. H. Asymptotic satellites near the equilibrium point in the isosceles triangle solution of the problem of three bodies. (Elliptical case.) Read (San Francisco Section) June 18, 1927. Transactions of the Royal Society of Canada, (3), vol. 21, Section III, pp. 377-390; May, 1927.

Garabedian, C. A. Correction de certains résultats sur la flexion d'une plaque circulaire épaisse donnés par de Saint-Venant dans la célèbre "Note finale du paragraphe 45 " de la traduction de Clebsch. Read Dec. 28, 1926. Journal de l'Ecole Polytechnique, (2), vol. 26, pp. 89$112 ; 1927$.

- Sur les plaques épaisses circulaires et rectangulaires chargées au centre. Read Dec. 29, 1927. Comptes Rendus de l'Académie des Sciences, vol. 186, No. 23, pp. 1518-1520; June 4, 1928.

Garver, R. Division algebras of order sixteen. Read Feb. 26, 1927. Annals of Mathematics, (2), vol. 28, No. 4, pp. 493-500; Sept., 1927.

- Tschirnhaus transformations on certain rational cubics. Read Oct. 29, 1927. American Mathematical Monthly, vol. 34, No. 10, pp. 521-525; Dec., 1927.

- A rational normal form for certain quartics. Read Oct. 29, 1927. This Bulletin, vol. 34, No. 1, pp. 73-74; Jan.-Feb., 1928.

- A new normal form for quartic equations. Read April 7, 1928. This Bulletin, vol. 34, No. 3, pp. 310-314; May-June, 1928.

The Tschirnhaus transformation. Read April 7, 1928. Annals of Mathematics, (2), vol. 29, No. 3, pp. 319-333; July, 1928.

Gehman, H. M. Concerning end points of continuous curves and other continua. Read April 2 and Sept. 9, 1926. Transactions of this Society, vol. 30, No. 1, pp. 63-84; Jan., 1928.

Concerning certain types of non-cut points, with an application to continuous curves. Read April 7, 1928. Proceedings of the National Academy of Sciences, vol. 14, No. 5, pp. 431-433; May, 1928.

- Concerning irreducible continua. Read Dec. 28, 1927. Proceedings of the National Academy of Sciences, vol. 14, No. 5, pp. 433-435; May, 1928.

Gergen, J. J. On generalized lacunae. Read April 16, 1927. American Journal of Mathematics, vol. 49, No. 3, pp. 407-418; July, 1927.

Gergen, J. J., and Widder, D. V. On Taylor's series admitting the circle of convergence as a singular curve. Read Sept. 9, 1927. American Journal of Mathematics, vol. 50, No. 1, pp. 139-146; Jan., 1928.

Glenn, O. E. Complete systems of differential invariants. Read Sept. 11, 1925. Proceedings of the London Mathematical Society, (2), vol. 27, No. 1, pp. 72-80; Sept., 1927.

- A memoir on the invariants of biternary quantics. Read May 1 and Sept. 9, 1926. American Journal of Mathematics, vol. 50, No. 2, pp. 209-230; April, 1928.

- Theorems of finiteness in formal concomitant theory, modulo $\mathrm{P}$. 
Read Dec. 28, 1920, and Feb. 26, 1921. Proceedings of the International Mathematical Congress held in Toronto, vol. I, pp. 331-345; 1928.

Differential combinants and associated parameters. Read May 3, 1924. Proceedings of the International Mathematical Congress held in Toronto, vol. I, pp. 373-385; 1928.

Griffiths, L. W. Generalized quaternion algebras and the theory of numbers. Read Sept. 9, 1926. American Journal of Mathematics, vol. 50, No. 2, pp. 302-314; April, 1928.

Gronwall, T. H., LaMer, V. K., and Sandved, K. Über den Einfluss der sogenannten höheren Glieder in der Debye-Hückelschen Theorie der Lösungen starker Elektrolyte. Read Oct. 30, 1926. Physikalische Zeitschrift, vol. 29, No. 12, pp. 358-393; June 15, 1928.

Grove, V. G. Transformations of nets. Read Dec. 31, 1926. Transactions of this Society, vol. 30, No. 3, pp. 483-497; July, 1928.

Haskell, M. W. Curves autopolar with respect to a finite number of conics. Read (San Francisco Section) Oct. 23, 1920. Proceedings of the International Mathematical Congress held in Toronto, vol. I, pp. 715$717 ; 1928$.

Hassler, J. O. Plane nets whose first and minus first Laplacian transforms each degenerate into a straight line. Read April 6, 1928. This Bulletin, vol. 34, No. 5, pp. 591-599; Sept.-Oct., 1928.

Hedrick, E. R. On derivatives of non-analytic functions. Read (San Francisco Section) April 7, 1928. Proceedings of the National Academy of Sciences, vol. 14, No. 8, pp. 649-654; Aug., 1928.

Hildebrandt, T. H. Note on interchange of order of limits. Read Sept. 8, 1927. This Bulletin, vol. 34, No. 1, pp. 79-81; Jan.-Feb., 1928.

Hill, L. S. Properties of certain aggregate functions. Read Sept. 9, 1926. American Journal of Mathematics, vol. 49, No. 3, pp. 419-432; July, 1927.

Hille, E. Note on the behavior of certain power series on the circle of convergence with application to a theorem of Carleman. Read Feb. 25, 1928. Proceedings of the National Academy of Sciences, vol. 14, No. 3, pp. 217-220; March, 1928.

A class of functional equations. Read Oct. 28, 1922. Annals of Mathematics, (2), vol. 29, No. 2, pp. 215-222; April, 1928.

Hodge, F. H. A generalization of the strophoid. Read April 15, 1922. American Mathematical Monthly, vol. 34, No. 10, pp. 527-529; Dec., 1927.

Hofmann, L., and Kasner, E. Homographic circles or clocks. With an appendix on polygenic functions by E. Kasner. Read Feb. 25, 1928. This Bulletin, vol. 34, No. 4, pp. 495-503; July-Aug., 1928.

Hollcroft, T. R. The generalized Hessian. Read May 7, 1927. Quarterly Journal of Mathematics, vol. 50, No. 4, pp. 362-372; Sept., 1927.

- On $(3,3)$ and higher point correspondences. Read Feb. 26, 1927. American Journal of Mathematics, vol. 49, No. 4, pp. 553-564; Oct., 1927.

- On nets of manifolds in $i$ dimensions. Read Oct. 29, 1927. Annali di Matematica, (4), vol. 5, No. 4, pp. 261-267; Sept., 1928. 
Hotelling, H. Differential equations subject to error, and population estimates. Read (San Francisco Section) April 2, 1927. Journal of the American Statistical Association, new ser., vol. 22, No. 159, pp. 283-314; Sept., 1927.

- Spaces of statistics and their metrization. Read Sept. 9, 1927. Science, new ser., vol. 67, No. 1728, pp. 149-150; Feb. 10, 1928.

Huntington, E. V. The notion of probable error in elementary statistics. Read Dec. 29, 1927. Science, new ser., vol. 66, No. 1722, pp. 633-637; Dec. 30, 1927.

- The apportionment of representatives in Congress. Read Dec. 28, 1920, Feb. 26, April 23, Sept. 8, and Dec. 28, 1921, and Feb. 25, 1922. Transactions of this Society, vol. 30, No. 1, pp. 85-110; Jan., 1928.

Hurwitz, W. A. On Bell's arithmetic of boolean algebras. Read April 7, 1928. Transactions of this Society, vol. 30, No. 2, pp. 420-424; April, 1928.

JACkson, D. A problem in minima. Read April 16, 1927. Annals of Mathematics, (2), vol. 28, No. 4, pp. 587-592; Sept., 1927.

- On the approximate representation of analytic functions. Read Sept. 8, 1927. This Bulletin, vol. 34, No. 1, pp. 56-62; Jan.-Feb., 1928. Some non-linear problems in approximation. Read Dec. 28, 1926. Transactions of this Society, vol. 30, No. 4, pp. 621-629; Oct., 1928.

JAMES, G. An integration method of summing series. Read (San Francisco Section) April 2, 1927. Annals of Mathematics, (2), vol. 29, No. 1, pp. 79-87; Dec., 1927.

KASNER, E. A new theory of polygenic (or non-monogenic) functions. Read Oct. 29, 1927. Science, new ser., vol. 66, No. 1720, pp. 581-582; Dec. 16, 1927.

- General theory of polygenic or non-monogenic functions. The derivative congruence of circles. Read Oct. 29 and Dec. 29, 1927. Proceedings of the National Academy of Sciences, vol. 14, No. 1, pp. 7582; Jan., 1928.

Transversality in space of three dimensions. Read Sept. 9 and Oct. 31, 1914. Transactions of this Society, vol. 30, No. 3, pp. 447-452; July, 1928.

Note on the derivative circular congruence of a polygenic function. Read Sept. 6, 1928. This Bulletin, vol. 34, No. 5, pp. 561-565; Sept.Oct., 1928.

- The second derivative of a polygenic function. Read April 6, 1928. Transactions of this Society, vol. 30, No. 4, pp. 803-818; Oct., 1928. See Hofmann, L.

Ketchum, P. W. Analytic functions of hypercomplex variables. Read Sept. 7, 1928. Transactions of this Society, vol. 30, No. 4, pp. 641-667; Oct., 1928.

KLINE, J. R. Separation theorems and their relation to recent developments in analysis situs. Read May 7, 1927. This Bulletin, vol. 34, No. 2, pp. 155-192; March-April, 1928.

KOopman, B. O. On the inversion of analytic transformations. Read 
Oct. 29, 1927. This Bulletin, vol. 34, No. 5, pp. 565-572; Sept.-Oct., 1928.

LaMer, V. K. See Gronwall, T. H.

LANE, E. P. Joint-axis congruences with indeterminate developables. Read Sept. 3, 1919. Tôhoku Mathematical Journal, vol. 29, Nos. 3-4, pp. 363-375; May, 1928.

- The projective differential geometry of systems of linear homogeneous differential equations of the first order. Read Dec. 29, 1927. Transactions of this Society, vol. 30, No. 4, pp. 785-796; Oct., 1928.

- Canonical configurations associated with a surface. Read Sept. 6, 1928. This Bulletin, vol. 34, No. 6, pp. 737-744; Nov.-Dec., 1928.

LANe, E. P., and Stouffer, E. B. Recent developments in projective differential geometry. Read April 6, 1928. This Bulletin, vol. 34, No. 4, pp. 453-472; July-Aug., 1928.

LANGER, R. E., and TAMARKIN, J. D. On integral equations with discontinuous kernels. Read Dec. 28, 1926. Transactions of this Society, vol. 30, No. 3, pp. 453-471; July, 1928.

LANGFord, C. H. Theorems on deducibility. Read Dec. 29, 1926. Annals of Mathematics, (2), vol. 28, No. 4, pp. 459-471; Sept., 1927.

- Concerning logical principles. Read (San Francisco Section) Oct. 29, 1927. This Bulletin, vol. 34, No. 5, pp. 573-582; Sept.-Oct., 1928.

LATIMER, C. G. On certain indefinite quaternary forms representing all integers. Read Sept. 9, 1927. Annals of Mathematics, (2), vol. 28, No. 3, pp. 327-329; July, 1927.

- A note on quaternary forms. Read Sept. 9, 1927. American Mathematical Monthly, vol. 34, No. 7, pp. 363-364; Sept., 1927.

Lubben, R. G. Concerning limiting sets in abstract spaces. Read Sept. 6, 1928. Transactions of this Society, vol. 30, No. 4, pp. 668-685; Oct., 1928.

The double elliptic case of the Lie-Riemann-Helmholtz-Hilbert problem of the foundations of geometry. Read Sept. 10, 1925. Fundamenta Mathematicae, vol. 11, pp. 35-95; 1928.

MACDuffee, C. C. A correspondence between matrices and quadratic ideals. Read April 15, 1927. Annals of Mathematics, (2), vol. 29, No. 2, pp. 199-214; April, 1928.

MARIA, A. J. Generalized derivatives. Read May 1, 1926. Annals of Mathematics, (2), vol. 28, No. 4, pp. 419-432; Sept., 1927.

Mathews, R. M. Cubic curves and desmic surfaces; second paper. Read April 2, 1926. Transactions of this Society, vol. 30, No. 1, pp. 19-23; Jan., 1928.

Mears, F. M. Riesz summability for double series. Read Sept. 9, 1927. Transactions of this Society, vol. 30, No. 4, pp. 686-709; Oct., 1928.

Merriman, G. M. Concerning the summability of double series of a certain type. Read May 7, 1927. Annals of Mathematics, (2), vol. 28, No. 4, pp. 515-533; Sept., 1927.

- The convergence of double Fourier series of a certain type. Read April 3, 1926. This Bulletin, vol. 34, No. 3, pp. 319-322; May-June, 1928. 
A set of necessary and sufficient conditions for the Cesàro summability of double series. Read April 3, 1926. Annals of Mathematics, (2), vol. 29, No. 3, pp. 343-354; July, 1928.

Miller, G. A. Number of systems of imprimitivity of transitive substitution groups. Read Dec. 28, 1927. Proceedings of the National Academy of Sciences, vol. 14, No. 1, pp. 82-84; Jan., 1928.

- Possible orders of two generators of the alternating and of the symmetric group. Read Dec. 31, 1926. Transactions of this Society, vol. 30, No. 1, pp. 24-32; Jan., 1928.

- Note on the history of logarithms. Read Sept. 9, 1926. Tôhoku Mathematical Journal, vol. 29, Nos. 3-4, pp. 308-311; May, 1928.

MiLne, W. E. The behavior of a boundary value problem as the interval becomes infinite. Read (San Francisco Section) June 2, 1928. Transactions of this Society, vol. 30, No. 4, pp. 797-802; Oct., 1928.

Moore, L. T. The nodes of the rational plane quartic. Read May 7, 1927. This Bulletin, vol. 34, No. 4, pp. 476-478; July-Aug., 1928.

Moore, L. T., and Neelley, J. H. Rational tacnodal and oscnodal quartic curves considered as plane sections of quartic surfaces. Read May 7, 1927. American Journal of Mathematics, vol. 50, No. 3, pp. 467-472; July, 1928.

Moore, R. L. Some separation theorems. Read Sept. 9, 1927. Proceedings of the National Academy of Sciences, vol. 13, No. 10, pp. 711-716; Oct., 1927.

- Concerning triods in the plane and the junction points of plane continua. Read Dec. 28, 1927. Proceedings of the National Academy of Sciences, vol. 14, No. 1, pp. 85-88; Jan., 1928.

- On the separation of the plane by a continuum. Read Dec. 28, 1927. This Bulletin, vol. 34, No. 3, pp. 303-306; May-June, 1928.

- A separation theorem. Read (San Francisco Section) June 18, 1927. Fundamenta Mathematicae, vol. 12, pp. 295-297; 1928.

MOoRE, T. W. On the invariant combinants of two binary quintics. Read Feb. 26, 1927. American Journal of Mathematics, vol. 50, No. 3, pp. 415-430; July, 1928.

MORITZ, R. E. On an extension of Glaisher's generalization of Wilson's theorem. Read (San Francisco Section) June 19, 1925. Tôhoku Mathematical Journal, vol. 28, Nos. 3-4, pp. 198-201; Sept., 1927.

- A modification of the reducing balance method of estimating depreciation. Read (San Francisco Section) June 18, 1927. The Accountant, vol. 77, No. 2761, pp. 614-617; Nov. 5, 1927.

- The general solution of a certain diophantine equation in three unknowns. Read (San Francisco Section) June 18, 1927. American Mathematical Monthly, vol. 35, No. 1, pp. 47-49; Jan., 1928.

Morley, F. See Coble, A. B.

MORSE, M. The foundations of a theory in the calculus of variations in the large. Read Dec. 30, 1924, and Sept. 9 and Dec. 29, 1926. Transactions of this Society, vol. 30, No. 2, pp. 213-274; April, 1928.

Musselman, J. R. On an imprimitive group of order 5184. Read Dec. 29, 1924, and May 7, 1927. American Journal of Mathematics, vol. 49, No.3, pp. 355-366; July, 1927. 
Neelley, J. H. Compound singularities of the plane rational quartic curve. Read Sept. 8 and Dec. 28, 1926. American Journal of Mathematics, vol. 49, No. 3, pp. 389-400; July, 1927.

A note on the rational plane quartic curve with cusps or undulations. Read Dec. 28, 1927. This Bulletin, vol. 34, No. 5, pp. 639-645; Sept.Oct., 1928.

See Moore, L. T.

Ore, O. Newtonsche Polygone in der Theorie der algebraischen Körper. Read Oct. 29, 1927. Mathematische Annalen, vol. 99, Nos. 1-2, pp. 84-117; April, 1928.

- Some theorems on the connection between ideals and group of a Galois field. Read Oct. 29, 1927. Transactions of this Society, vol. 30, No. 3, pp. 610-620; July, 1928.

Perkins, F. W. An intrinsic treatment of Poisson's integral. Read Jan. 2, 1926. American Journal of Mathematics, vol. 50, No. 3, pp. 389-414; July, 1928.

Pfeiffer, G. A. A property of the level lines of a region with a rectifiable boundary. Read May 7, 1927. This Bulletin, vol. 34, No. 5, pp. 656664; Sept.-Oct., 1928.

Pierpont, J. Optics in spaces of constant non-vanishing curvature. Read Feb. 26, 1927. American Journal of Mathematics, vol. 49, No. 3, pp. 343-354; July, 1927.

- Optics in hyperbolic space. Read Dec. 29, 1926. Transactions of this Society, vol. 30, No. 1, pp. 33-48; Jan., 1928.

- Mathematical rigor, past and present. Read Dec. 28, 1927. This Bulletin, vol. 34, No. 1, pp. 23-53; Jan.-Feb., 1928.

- On the geometry whose absolute is a ruled quadric. Read May 7, 1927. Monatshefte für Mathematik und Physik, vol. 35, No. 1, pp. 111$128 ; 1928$.

Rainich, G. Y. Principle of paraphrase, second form. Read Jan. 1, 1926. Printed in E. T. Bell's Algebraic arithmetic, American Mathematical Society Colloquium Publications, vol. 7, pp. 69-72; 1927.

- Radiation and relativity. I. Read April 15, 1927. Proceedings of the National Academy of Sciences, vol. 14, No. 6, pp. 484-488; June, 1928.

- Radiation and relativity. II. Read Dec. 31, 1926. Proceedings of the National Academy of Sciences, vol. 14, No. 8, pp. 654-657; Aug., 1928.

Rawles, T. H. Two classes of periodic orbits with repelling forces. Read Feb. 25, 1928. This Bulletin, vol. 34, No. 5, pp. 618-630; Sept.-Oct., 1928.

The invariant integral and the inverse problem in the calculus of variations. Read Dec. 28, 1927. Transactions of this Society, vol. 30, No. 4, pp. 765-784; Oct., 1928.

REYNoLDS, C. N. On the problem of coloring maps in four colors, II. Read Dec. 28, 1923 and Dec. 29, 1926. Annals of Mathematics, (2), vol. 28, No. 4, pp. 477-492; Sept., 1927. 
Some theorems on the zeros of solutions of self-adjoint homogeneous linear differential equations of the fifth order. Read Sept. 2, 1919. Bulletin of the West Virginia University Scientific Association, vol. 3, No. 1, pp. 26-32; Aug., 1926 (published in 1928).

RICHARDSON, R. G. D. A problem in the calculus of variations with an infinite number of auxiliary conditions. Read Sept. 11, 1925. Transactions of this Society, vol. 30, No. 1, pp. 155-189; Jan., 1928.

Richmond, D. E. Geodesics on surfaces of genus zero with knobs. Read Jan. 2, 1926. Transactions of this Society, vol. 30, No. 1, pp. 49-62; Jan., 1928.

Number relations between types of extremals joining a pair of points. Read May 7 and Oct. 29, 1927. American Journal of Mathematics, vol. 50, No. 3, pp. 371-388; July, 1928.

RIDER, P. R. Minimizing two types of definite integral. Read Dec. 28, 1927. Annals of Mathematics, (2), vol. 29, No. 2, pp. 189-193; April, 1928.

RITT, J.F. On certain points in the theory of Dirichlet series. Read Oct. 29, 1927. American Journal of Mathematics, vol. 50, No. 1, pp. 73-86; Jan., 1928.

Robertson, H. P. Bemerkung über separierbare Systeme in der Wellenmechanik. Read Oct. 29, 1927. Mathematische Annalen, vol. 98, No. 5, pp. 749-752; Jan., 1928.

Roos, C. F. A dynamical theory of economics. Read Oct. 29, 1927. Journal of Political Economy, vol. 35, No. 5, pp. 632-636; Oct., 1927. A mathematical theory of depreciation and replacement. Read Sept. 9, 1927. American Journal of Mathematics, vol. 50, No. 1, pp. 147-157; Jan., 1928.

The problem of depreciation in the calculus of variations. Read Sept. 9, 1927. This Bulletin, vol. 34, No. 2, pp. 218-228; MarchApril, 1928.

- Generalized Lagrange problems in the calculus of variations. Read Dec. 31, 1926. Transactions of this Society, vol. 30, No. 2, pp. 360-384; April, 1928.

Roth, W. E. A solution of the matric equation $P(X)=A$. Read Dec. 29, 1927. Transactions of this Society, vol. 30, No. 3, pp. 579-596; July, 1928.

Sandved, K. See Gronwall, T. H.

SchelkunOFF, S. A. On certain properties of the metrical and generalized metrical groups in linear spaces of $n$ dimensions. Read Sept. 8, 1927. Dissertation, Columbia. Hamburg, Lütcke and Wulff, 1927. $8+42 \mathrm{pp}$.

SeEly, C. Kernels of positive type. Read Oct. 29, 1927. Annals of Mathematics, (2), vol. 29, No. 3, pp. 313-318; July, 1928.

Serghiesco, S. Sur le nombre des racines communes à plusieurs équations simultanées. Read Feb. 25, 1928. Abstract in Comptes Rendus de l'Académie des Sciences, vol. 186, No. 4, pp. 211-213; Jan. 23, 1928.

Shaub, H. C. Rational involutorial transformations in $S_{4}$ which leave invariant $\infty^{4}$ quadric varieties. Read Oct. 30, 1926. American Journal of Mathematics, vol. 49, No. 3, pp. 367-382; July, 1927. 
Sheffer, I. M. On entire function interpolation. Read Dec. 31, 1926. American Journal of Mathematics, vol. 49, No. 3, pp. 329-342; July, 1927.

Shoнат, J. A. (Снокнate, J.). Sur la convergence des quadratures mécaniques dans un intervalle infini. Application au problème des moments, au calcul des probabilités. Read April 7, 1928. Abstract in Comptes Rendus de l'Académie des Sciences, vol. 186, No. 6, pp. 344346; Feb. 6, 1928.

Simmons, H. A. Strong and weak inequalities involving the ratio of two chords or arcs of a circle; chains of inequalities. Read Dec. 28, 1927. American Mathematical Monthly, vol. 35, No. 3, pp. 122-130; March, 1928.

SLotnick, M. M. A contribution to the theory of fundamental transformations of surfaces. Read Oct. 29, 1927. Transactions of this Society, vol. 30, No. 1, pp. 190-212; Jan., 1928.

- A method of applying tensor analysis to the study of rectilinear congruences. Read Oct. 29, 1927. Mathematische Zeitschrift, vol. 28, No. 1, pp. 107-115; March, 1928.

Sмiтн, H. L. On relative content and Green's lemma. Read April 3, 1926. Transactions of this Society, vol. 30, No. 2, pp. 405-419; April, 1928.

Stone, M. H. A characteristic property of certain sets of trigonometric functions. Read Feb. 26, 1927. American Journal of Mathematics, vol. 49, No. 4, pp. 535-542; Oct., 1927.

- The normal probability function and general frequency functions. Read Feb. 26, 1927. American Journal of Mathematics, vol. 49, No. 4, pp. 543-552; Oct., 1927.

Stouffer, E. B. Expressions for the general determinant in terms of its principal minors. Read April 2, 1926. American Mathematical Monthly, vol. 35, No. 1, pp. 18-21; Jan., 1928.

- Some canonical forms and associated canonical expansions in projective differential geometry. Read (Southwestern Section) Nov. 26, 1927. This Bulletin, vol. 34, No. 3, pp. 290-302; May-June, 1928.

- See Lane, E. P.

Struik, D. J., and Wiener, N. A relativistic theory of quanta. Read May 7, 1927. Journal of Mathematics and Physics of the Massachusetts Institute of Technology, vol. 7, No. 1, pp. 1-23; Nov., 1927.

- The fifth dimension in relativistic quantum theory. Read Dec. 29, 1927. Proceedings of the National Academy of Sciences, vol. 14, No. 3, pp. 262-268; March, 1928.

Sturdivant, J. H. Second-order linear systems with summable coefficients. Read Sept. 9, 1926. Transactions of this Society, vol. 30, No. 3, pp. 560-566; July, 1928.

Swingle, P. M. An unnecessary condition in two theorems of analysis situs. Read Dec. 29, 1925. This Bulletin, vol. 34, No. 5, pp. 607-618; Sept.-Oct., 1928.

Tamarkin, J. D. See Langer, R. E.

TAYLOR, J. H. Parallelism and transversality in a sub-space of a general (Finsler) space. Read April 16, 1927. Annals of Mathematics, (2), vol. 28, No. 4, pp. 620-628; Sept., 1927. 
Thомаs, J. M. Incomplete systems of partial differential equations. Read Sept. 7, 1928. Proceedings of the National Academy of Sciences, vol. 14, No. 8, pp. 666-670; Aug., 1928.

TRJITZINSKY, W. J. Relations satisfied by coefficients of periodic solutions. Read (San Francisco Section) June 18, 1927. Annals of Mathematics, (2), vol. 29, No. 1, pp. 17-20; Dec., 1927.

Representation of functions determined by their initial values. Read (San Francisco Section) June 18, 1927. Annals of Mathematics, (2), vol. 29, No. 1, pp. 73-78; Dec., 1927.

Expansion in series of non-inverted factorials. Read Sept. 9, 1927. This Bulletin, vol. 34, No. 2, pp. 193-196; March-April, 1928.

U'spensky, J. V. On the development of arbitrary functions in series of Hermite's and Laguerre's polynomials. Read Dec. 31, 1926. Annals of Mathematics, (2), vol. 28, No. 4, pp. 593-619; Sept., 1927.

- On Jacobi's arithmetical theorems concerning the simultaneous representation of numbers by two different quadratic forms. Read Diec. 31, 1926. Transactions of this Society, vol. 30, No. 2, pp. 385-404; April, 1928.

On the convergence of quadrature formulas related to an infinite interval. Read April 16, 1927. Transactions of this Society, vol. 30, No. 3, pp. 542-559; July, 1928.

VANDiver, H. S. Transformations of the Kummer criteria in connection with Fermat's last theorem. (Second paper.) Read Dec. 29, 1926. Annals of Mathematics, (2), vol. 28, No. 4, pp. 451-458; Sept., 1927.

Veblen, O. Projective tensors and connections. Read Dec. 29, 1927. Proceedings of the National Academy of Sciences, vol. 14, No. 2, pp. 154166; Feb., 1928.

WALSH, J. L. On the expansion of analytic functions in series of polynomials and in series of other analytic functions. Read Sept. 9, 1927. Transactions of this Society, vol. 30, No. 2, pp. 307-332; April, 1928. On approximation to an arbitrary function of a complex variable by polynomials. Read Dec. 28, 1927. Transactions of this Society, vol. 30, No. 3, pp. 472-482; July, 1928.

- On the degree of approximation to an analytic function by means of rational functions. Read Sept. 7, 1928. Transactions of this Society, vol. 30, No. 4, pp. 838-847: Oct., 1928.

WARD, M. General arithmetic. Read (San Francisco Section) Oct. 29, 1927. Proceedings of the National Academy of Sciences, vol. 13, No. 11, pp. 748-749; Nov., 1927.

Weaver, J. H. Properties of two points associated with a triangle. Read Sept. 8, 1927. American Mathematical Monthly, vol. 35, No. 7, pp. 349-352; Aug.-Sept., 1928.

WeISNER, L. Quadratic fields in which cyclotomic polynomials are reducible. Read Oct. 29, 1927. Annals of Mathematics, (2), vol. 29, No. 3, pp. 377-381; July, 1928.

Polynomials $f[\phi(x)]$ reducible in fields in which $f(x)$ is irreducible. Read Feb. 25, 1928. This Bulletin, vol. 34, No. 6, pp. 745-751; Nov.-Dec., 1928. 
WeIss, M. J. Primitive groups which contain substitutions of prime order $p$ and of degree $6 p$ or $7 p$. Read (San Francisco Section) Oct. 29, 1927. Transactions of this Society, vol. 30, No. 2, pp. 333-359; April, 1928.

WHEELER, A. P. Linear ordinary self-adjoint differential equations of the second order. Read Jan. 1, 1926. American Journal of Mathematics, vol. 49, No. 3, pp. 309-320; July, 1927.

WhybURn, G. T. Concerning the open subsets of a plane continuous curve. Read Dec. 31, 1926, and Feb. 26, 1927. Proceedings of the National Academy of Sciences, vol. 13, No. 9, pp. 650-657; Sept., 1927.

- Concerning the structure of a continuous curve. Read Dec. 31, 1926, and (San Francisco Section) June 18, 1927. American Journal of Mathematics, vol. 50, No. 2, pp. 167-194; April, 1928.

Concerning the cut points of continua. Read Sept. 9, 1927. Transactions of this Society, vol. 30, No. 3, pp. 597-609; July, 1928.

Concerning accessibility in the plane and regular accessibility in $n$ dimensions. Read Dec. 29, 1927. This Bulletin, vol. 34, No. 4, pp. 504-510; July-Aug., 1928.

Concerning plane closed point sets which are accessible from certain subsets of their complements. Read Dec. 28, 1927. Proceedings of the National Academy of Sciences, vol. 14, No. 8, pp. 657-666; Aug., 1928.

— On a problem of W. L. Ayres. Read Sept. 9, 1927. Fundamenta Mathematicae, vol. 11, pp. 296-301; 1928.

Concerning Menger regular curves. Read Sept. 9 and (Southwestern Section) Nov. 26, 1927. Fundamenta Mathematicae, vol. 12, pp. 264$294 ; 1928$.

On certain accessible points of plane continua. Read Feb. 25 and April 8, 1928. Monatshefte für Mathematik und Physik, vol. 35, No. 2, pp. 289-304; 1928.

- See Ayres, W. L.

Whyburn, W. M. Second-order differential systems with integral and $k$-point boundary conditions. Read Feb. 26 and April 16, 1927. Transactions of this Society, vol. 30, No. 4, pp. 630-640; Oct., 1928.

- Existence and oscillation theorems for non-linear differential systems of the second order. Read Sept. 9, 1927. Transactions of this Society, vol. 30, No. 4, pp. 848-854; Oct., 1928.

WIDDER, D. V. The singularities of a function defined by a Dirichlet series. Read April 16, 1927. American Journal of Mathematics, vol. 49, No. 3, pp. 321-328; July, 1927.

A generalization of Taylor's series. Read Dec. 29, 1926. Transactions of this Society, vol. 30, No. 1, pp. 126-154; Jan., 1928.

- See Gergen, J. J.

WiEner, N. Coherency matrices and quantum theory. Read April 6, 1928. Journal of Mathematics and Physics of the Massachusetts Institute of Technology, vol. 7, No. 2, pp. 109-125; June, 1928.

A new method in Tauberian theorems. Read Feb. 26, 1927. Journal of Mathematics and Physics of the Massachusetts Institute of Technology, vol. 7, No. 3, pp. 161-184; Oct., 1923. 
See Struik, D. J.

WILDER, R. L. On connected and regular point sets. Read April 7, 1928. This Bulletin, vol. 34, No. 5, pp. 649-655; Sept.-Oct., 1928.

Concerning R. L. Moore's axioms $\Sigma_{1}$ for plane analysis situs. Read Dec. 28, 1927. This Bulletin, vol. 34, No. 6, pp. 752-760; Nov.-Dec., 1928.

A characterization of continuous curves by a property of their open subsets. Read April 2, 1926. Fundamenta Mathematicae, vol. 11, pp. $127-131 ; 1928$.

On a certain type of connected set which cuts the plane. Read Dec. 30, 1924. Proceedings of the International Mathematical Congress held in Toronto, vol. I, pp. 423-437; 1928.

Williams, A. R. Rational quintic surfaces with two skew double lines. Read (San Francisco Section) April 2, 1927. This Rulletin, vol. 34, No. 5, pp. 631-639; Sept.-Oct., 1928.

- The Muntesano quintic surface. Read (San Francisco Section) April 7, 1928. This Bulletin, vol. 34, No. 6, pp. 761-770; Nov.-Dec., 1928.

Williams, K. P. A comment on certain equations in the theory of radiative equilibrium. Read April 7, 1928. Astrophysical Journal, vol. 47, No. 4, pp. 296-304; May, 1928.

Williamson, J. Conditions for associativity of division algebras connected with non-abelian groups. Read April 2 and Dec. 31, 1926. Transactions of this Society, vol. 30, No. 1, pp. 111-125; Jan., 1928.

Wilson, W. A. On bounded regular frontiers in the plane. Read Oct. 29, 1927. This Bulletin, vol. 34, No. 1, pp. 81-90; Jan.-Feb., 1928.

- On irreducible cuts of the plane between two points. Read Sept. 9, 1927. Annals of Mathematics, (2), vol. 29, No. 3, pp. 382-388; July, 1928.

- Some properties of upper semi-continuous collections of bounded continua. Read Feb. 25, 1928. This Bulletin, vol. 34, No. 5, pp. 599606; Sept.-Oct., 1928.

Winger, R. M. The equianharmonic cubic and its group. Read (San Francisco Section) June 18, 1927. Tôhoku Mathematical Journal, vol. 29, Nos. 3-4, pp. 376-400; May, 1928.

Young, J. W. A new formulation for general algebra. Read Dec. 28, 1911, April 26, 1913, Sept. 9, 1926, and Feb. 26, 1927. Annals of Mathematics, (2), vol. 29, No. 1, pp. 47-60; Dec., 1927.

ZARYCKI, M. Allgemeine Eigenschaften der Cantorschen Kohärenzen. Read Feb. 25, 1928. Transactions of this Society, vol. 30, No. 3, pp. 498-506; July, 1928. 